\title{
New this month
}

\section{- Public sector finances - Chapter 1}

Public sector net borrowing in January 2009 was minus £3.3 billion [Table 1.1A].

Public sector net debt was equivalent to 47.8 per cent of GDP at end January 2009 [Table 1.1A].

\section{- Central government revenue and expenditure - Chapter 2}

HM Revenue and Customs (HMRC) cash receipts were $£ 52.9$ billion in January 2009, compared to $£ 56.6$ billion in January 2008 [Table 2.1A].

\section{- Notes and Coin Reserve Balances - Chapter 3}

The notes and coin reserve balances (monthly average) January 2009 one month growth rate was 1.1 per cent (seasonally adjusted) and the twelve months growth rate to January 2009 was 7.7 per cent [Table 3.1A].

Seasonally adjusted M4 grew by 2.5 per cent in January 2009. The twelve month growth rate to January 2009 was 17.5 per cent [Table S3.1A].

\section{- Unit trusts - Chapter 5}

The total funds of unit trusts decreased to $£ 354.2$ billion at end January 2009 from $£ 361.1$ billion at end December 2008. In January 2009 the total gross sales amounted to $£ 8.5$ billion, and repurchase of units to $£ 6.6$ billion, giving net sales of $£ 1.9$ billion. The total funds invested in Individual Savings Accounts (ISAs) was $£ 70.8$ billion at end January 2009 [Table 5.3D].

The number of unit holdings (accounts) were 15.2 million at the end of January 2009 compared with 16.4 million holdings at the end of January 2008 [Table 5.3D].

\section{- Capital issuance by instruments (UK residents, all currencies - Chapter 6}

Capital issuance by instrument (UK residents, all currencies): Total net issuance (series B24K) in January 2009 amounted to $£ 18.4$ billion compared with $£ 131.7$ billion in December 2008 [Table $6.2 \mathrm{~A}]$.

\section{- Exchange rates - Chapter 7}

The average effective exchange rate index (January 2005=100) of sterling was 78.3 in February 2009 compared with 76.6 in January 2009. The average rate against the US dollar decreased to $\$ 1.44$ in February 2009 from $\$ 1.45$ in January 2009. The average rate against the Japanese yen increased to $¥ 133.8$ in February 2009 compared with $¥ 130.4$ in January 2009 . The average rate against the Euro was $€ 1.13$ in February 2009 [Table 7.1A].

\section{Selected retail banks: interest rates- Chapter 7}

As from $5^{\text {th }}$ March 2009 the base rate was decreased to 0.5 percent [Table 7.1J].

\section{Consumer prices index (CPI) and Retail prices index (RPI) - Chapter 7}

In the twelve months to January 2009, the consumer prices index (CPI) rose by 3.0 per cent, down from 3.1 per cent in December 2008.

In the twelve months to January 2009 , the all items retail prices index (RPI) rose by 0.1 per cent, down from 0.9 per cent in December 2008.[Table 7.2A]. 